\title{
STRATEGI PEMASARAN JAMUR TIRAM DI KOTA MATARAM
}

\section{MARKETING STRATEGY OF OYSTER MUSHROOMS IN MATARAM CITY}

\author{
Ulfah Nuraini $^{1}{ }^{*}$, L. Sukardi ${ }^{2}$, Efendy $^{3}$ \\ ${ }^{1,2,3}$ Program Studi Agribisnis, Universitas Mataram, Kota Mataram, Indonesia. \\ *Email Penulis Korespondensi: evy04121964@gmail.com
}

\begin{abstract}
ABSTRAK
Penelitian ini bertujuan untuk: (1) Mengetahui saluran pemasaran jamur tiram di Kota Mataram; (2) Mengetahui faktor internal dan eksternal usaha pemasaran jamur tiram di Kota Mataram; (3) Mengetahui strategi pemasaran jamur tiram di Kota Mataram. Penelitian ini menggunakan metode deskriptif. Penentuan daerah sampel dilakukan dengan metode purposive sampling. Jumlah responden ditentukan secara sensus sebanyak 19 orang petani jamur tiram. Teknik dan cara yang digunakan dalam pengumpulan data dalam penelitian ini yaitu teknik survey dan alat analisis yang digunakan adalah Analisis SWOT. Hasil penelitian menunjukkan bahwa; Hasil penelitian menunjukkan bahwa: (1) Saluran pemasaran jamur tiram di Kota Mataram ada dua saluran. Saluran I: Produsen - Konsumen Akhir dengan harga jual Rp $22.500 / \mathrm{kg}$. Saluran II: Produsen - Pedagang Pengecer - Konsumen Akhir dengan harga jual Rp 27.500/kg; (2) Dari hasil analisis SWOT diketahui faktor internal (kekuatan dan kelemahan) dan faktor eksternal (peluang dan ancaman) usaha jamur tiram di Kota Mataram. Kekuatannya adalah: Kualitas jamur tiram yang baik, Besarnya modal yang terjangkau, Penetapan harga yang kompetitif, Mempertahankan pelanggan. Kelemahannya adalah: Masih kurangnya kegiatan promosi, Kurang adanya sistem pemasaran, Proses produksi masih menggunakan teknologi sederhana. Peluangnya adalah: Pangsa pasar jamur tiram yang masih luas, Jamur tiram dapat diolah menjadi produk turunan, Intervensi pemerintah. Ancamannya adalah: Adanya persaingan antara pembudidaya jamur tiram, Pengaruh pergantian musim/cuaca; (3) Strategi pemasaran yang dapat dilakukan oleh petani jamur adalah pertumbuhan agresif (growth oriented strategy) yaitu dengan memperluas pangsa, dan melalui peningkatkan nilai tambah dengan melakukan pengolahan produk dari jamur tiram segar.
\end{abstract}

Kata kunci: Strategi Pemasaran, Jamur Tiram, Analisis SWOT

\begin{abstract}
The objectives of this research are: (1) Knowing marketing channels for oyster mushrooms in the city of Mataram; (2) Knowing the internal and external factors of the oyster mushrooms marketing business in the city of Mataram; (3) Knowing marketing strategy of oyster mushrooms in the city of Mataram. This research uses descriptive method. Determination of the sample area is done by puposive sampling method. The number of respondents was determined by a census of 19 oyster mushroom farmers. The techniques and methods used in data collection in this research is survey techniques and this research is analyzed by SWOT analysis. The results showed that: (1) There are two channels for marketing oyster mushrooms. Channel I: Producer Final Consumer with a selling price of IDR 22,500 / kg. Channel II: Producer - Retailer - Final Consumer with a selling price of Rp. 27,500s / kg; (2) From the results of the SWOT analysis it is known that internal factors (strengths and weaknesses) and external factors (opportunities and threats) of oyster mushroom business in the city of Mataram. Its strengths are: Good quality oyster mushrooms, Amount of affordable capital, Competitive pricing, Retain customers. The disadvantages are: The lack of promotion activities, the lack of a marketing system, the production process still uses simple technology. The opportunities are: oyster mushroom market share is still wide, oyster mushrooms can be processed into derivative products, government intervention. The threats are: The existence of competition between oyster mushroom growers, Effect of seasonal / weather changes; (3) The marketing strategy that can be carried out by mushroom growers is aggressive growth (growth oriented strategy) that is by expanding the share, and by increasing added value by processing products from fresh oyster mushrooms.

Keywords: Marketing strategy, Oyster Mushroom, SWOT analysis
\end{abstract}

Nuraini, U., Sukardi, L., dan Efendy 


\section{PENDAHULUAN}

\section{Latar Belakang}

Usaha hortikultura merupakan komponen penting dalam pembangunan pertanian yang terus bertumbuh dan berkembang dari waktu ke waktu. Pasar produk komoditas tersebut bukan hanya untuk memenuhi kebutuhan pasar di dalam negeri saja, melainkan juga sebagai komoditas ekspor yang dapat menghasilkan devisa untuk negara. Di lain pihak, konsumen semakin menyadari arti penting produk hortikultura yang bukan hanya untuk memenuhi kebutuhan pangan semata tetapi juga mempunyai manfaat untuk kesehatan, estetika, dan menjaga lingkungan hidup (Kementan, 2015).

Salah satu komoditas hortikultura dari kelompok sayuran yang potensial untuk dikembangkan dan memiliki prospek adalah jamur. Keberadaan jamur sebagai salah satu jenis bahan pangan telah cukup lama dikenal oleh masyarakat di Indonesia sebagai salah satu bahan pangan yang memiliki manfaat baik untuk kesehatan. Jamur memiliki kandungan protein nabati yang tinggi, karbohidrat yang sebanding, serta kandungan lemak yang lebih rendah dari daging namun sebanding dengan sayur-sayuran lain. Dengan demikian, jamur merupakan pilihan tepat untuk dikonsumsi sebagai alternatif menu makanan sehat. (Pasaribu, 2002).

Jamur tiram sebagai salah satu jenis jamur yang dibudidayakan memiliki beberapa keunggulan dibandingkan jenis jamur lainnya. Beberapa keunggulan jamur tiram adalah: (a) budidaya jamur tiram dapat berlangsung sepanjang tahun, menjadikan produksi jamur tiram yang terus menerus, (b) budidaya jamur tiram dapat dilaksanakan dalam areal yang relatif sempit, sehingga menjadi alternatif yang baik untuk memanfaatkan lahan pekarangan, (c) budidaya jamur tiram menggunakan bahan baku serbuk kayu yang mudah diperoleh, (d) tingkat kesulitan budidaya yang relatif lebih mudah dibandingkan jenis jamur lainnya, (e) jamur tiram memiliki masa produksi hingga masa panen yang paling cepat diantara jamur-jamur lain, dan (f) jamur tiram memiliki tingkat harga jual yang relatif baik dan stabil dibandingkan jamur-jamur lain (Soenanto, 2000).

Jamur tiram merupakan salah satu jenis tanaman pangan yang mempunyai nilai ekonomis tinggi (Candra et al, 2014). Jamur tiram sebagai salah satu jenis jamur yang dibudidayakan memiliki banyak keunggulan dibandingkan jenis jamur lainnya (Hermawan et al., 2017). Sebagian masyarakat pun menyadari peluang bisnis yang muncul dalam usaha budidaya jamur tiram. Hal ini didukung dari hasil penelitian yang mengungkapkan bahwa kesadaran masyarakat untuk mengkonsumsi jamur berpengaruh positif terhadap permintaan pasokan yang meningkat mencapai 20\%-25\% per tahun (Agrina, 2009). Menurut Sarina (2012) jumlah konsumsi jamur Indonesia rata-rata adalah 0,197 kg per kapita per tahun. Jumlah yang cukup tinggi.

Salah satu kota yang membudidayakan jamur tiram yaitu Kota Mataram. Kegiatan budidaya jamur tiram mulai menghadapi permasalahan. Indikasi yang menunjukkan adanya permasalahan itu yakni karena mengalami keterbatasan modal dan dalam proses produksi belum menggunakan teknologi dan tenaga mesin yang sederhana sehingga kapasitas produksi usaha belum bisa meningkat. Permasalahan lainnya yaitu, daya simpan jamur tiram setelah panen tidak tahan lama sehingga harus segera dipasarkan. Berdasarkan uraian yang telah dijelaskan di atas penulis tertarik untuk mengetahui faktor internal dan eksternal pemasaran yang dihadapi oleh usaha jamur tiram di Kota Mataram dalam kaitannya dengan aspek pemasaran sehingga dapat mengembangkan kegiatan usaha jamur tiram tersebut.

Nuraini, U., Sukardi, L., dan Efendy 
Dari uraian latar belakang di atas permasalahan yang ada maka perlu dilakukan penelitian mengenai "Strategi Pemasaran Jamur Tiram di Kota Mataram." Penelitian ini bertujuan untuk: (1) Mengetahui saluran pemasaran jamur tiram di Kota Mataram; (2) Mengetahui faktor internal dan eksternal usaha pemasaran jamur tiram di Kota Mataram; (3) Mengetahui strategi pemasaran jamur tiram di Kota Mataram.

\section{METODE PENELITIAN}

\section{Metode Penelitian}

Metode dasar yang digunakan dalam penelitian ini adalah metode deskriptif yang meneliti status kelompok manusia, suatu objek, suatu set kondisi, suatu sistem pemikiran, ataupun suatu kelas peristiwa pada masa sekarang. Tujuan dari penelitian deskriptif adalah untuk membuat deskripsi, gambaran atau lukisan secara sistematis, factual dan akurat mengenai fakta-fakta, sifat-sifat serta hubungan antar fenomena yang diselidikI (Nazir, 2017).

\section{Unit Analisis}

Unit yang dianalisis dalam penelitian ini adalah petani yang melakukan usahatani jamur tiram yang ada di Kota Mataram.

\section{Teknik Penentuan Sampel}

\section{Penentuan Daerah Penelitian}

Penentuan daerah penelitian dilakukan dengan metode purposive sampling, yaitu memilih daerah yang paling banyak terdapat usahatani jamur tiram. Dari 6 kecamatan yang ada di Kota Mataram dipilih Kecamatan Ampenan di Kelurahan Ampenan Selatan dan Kecamatan Mataram di Kelurahan Pagutan sebagai daerah penelitian.

\section{Penentuan Responden Penelitian}

Penentuan jumlah responden dilakukan dengan metode sensus, yaitu semua populasi dijadikan sampel. Adapun besar sampel adalah sebanyak 19 petani jamur tiram, yang di tetapkan di dua kecamatan yaitu Kecamatan Ampenan di Kelurahan Ampenan Selatan sebanyak 10 responden dan Kecamatan Mataram di Kelurahan Pagutan sebanyak 9 responden.

\section{Jenis dan Sumber Data \\ Jenis Data}

Jenis data yang digunakan dalam penelitian ini adalah data kualitatif dan data kuantitatif.

\section{Sumber Data}

Sumber data dalam penelitian ini adalah berupa data primer dan data sekunder. Data primer yaitu data yang diperoleh dari hasil observasi dan wawancara langsung dengan petani jamur tiram yang berpedoman pada daftar pertanyaan yang sudah dipersiapkan. Data sekunder yaitu data yang diperoleh dari dinas atau instansi lain yang terkait dengan penelitian ini, dan data atau pustaka lainnya yang mendukung. 


\section{Variabel dan Cara Pengukurannya}

Variabel-variabel yang diukur dalam penelitian ini yaitu:

1. Harga yang dimaksud dalam penelitian ini adalah harga jamur tiram yang berlaku dinyatakan dalam satuan rupiah per kilogram $(\mathrm{Rp} / \mathrm{Kg})$.

2. Saluran pemasaran yang dimaksud dalam penelitian ini adalah jalur yang dilalui oleh jamur tiram dari produsen sampai ke konsumen akhir.

3. Kekuatan merupakan suatu keunggulan sumberdaya, keterampilan atau kemampuan biaya lainnya yang relative terhadap pesaing, dan kebutuhan pasar yang dilayani atau hendak dilayani oleh petani jamur tiram.

4. Kelemahan merupakan keterbatasan atau kekurangan dalam sumber daya, keterampilan dan kemampuan yang secara serius menghalangi kinerja usaha jamur tiram.

5. Peluang merupakan situasi utama yang paling menguntungkan dalam lingkungan usaha jamur tiram.

6. Ancaman merupakan situasi utama yang tidak menguntungkan dalam lingkungan usaha jamur tiram.

7. Strategi yaitu cara untuk mencapai sebuah tujuan berdasarkan analisa terhadap faktor internal dan eksternal.

8. Pemasaran yang dimaksud dalam penelitian ini adalah segala usaha yang dilakukan petani jamur tiram untuk merencanakan, menentukan harga, mempromosikan, dan mendistribusikan jamur tiram ke konsumen untuk memenuhi kebutuhan masyarakat melalui proses pertukaran.

9. Lingkungan internal yaitu berbagai hal atau pihak yang terkait langsung dengan kegiatan sehari-hari dalam suatu pemasaran dan mempengaruhi langsung setiap kegiatan pemasaran. Lingkungan internal terdiri dari strengths (kekuatan) dan weakness (kelemahan).

10. Lingkungan eksternal yaitu lingkungan yang mempengaruhi organisasi dari luar. Lingkungan eksternal terdiri dari opportunities (peluang) dan threats (ancaman).

11. Strategi pemasaran yaitu pola pikir pemasaran yang akan digunakan untuk mencapai tujuan pemasaran. Strategi pemasaran berisi strategi spesifik untuk pemilihan pasar, perencanaan produk, penetapan harga, sistem distribusi, promosi.

\section{Teknik Pengumpulan Data}

Pengumpulan data dilakukan dengan teknik survey, yaitu teknik pengumpulan data yang dilakukan untuk mengumpulkan informasi yang dilakukan dengan cara menyusun daftar pertanyaan melalui kuisioner dan wawancara yang diajukan pada responden.

\section{Analisis Data}

\section{Saluran Pemasaran}

Untuk mengetahui saluran pemasaran jamur tiram di Kota Mataram ditelusuri secara snow ball sampling yaitu menulusuri rantai pemasaran jamur tiram mulai dari responden petani (produsen) hingga ke konsumen akhir. 


\section{Analisis Faktor Internal dan Eksternal Usaha Pemasaran Jamur Tiram}

Untuk mengetahui faktor internal dan eksternal usaha pemasaran jamur tiram digunakan metode IFAS, EFAS untuk menghitung skor pembobotan pada tiap-tiap faktor internal dan eksternal.

Analisis pada tahap masukan yang merupakan tahap awal dari perumusan strategi pemasaran yang akan digunakan sebagai masukan informasi pada tahap selanjutnya. Analisis internal perusahaan merupakan perumusan kekuatan dan kelemahan dalam melakukan usahatani jamur tiram.

Untuk matriks IFAS, skala nilai peringkat (rating) untuk kekuatan dan kelemahan yang digunakan adalah sebagai berikut.

Tabel 1. Matriks IFAS

$\begin{array}{ll}1=\text { kekuatan yang kecil } & 1=\text { kelemahan yang sangat } \\ 2=\text { kekuatan yang sedang } & \text { berarti } \\ 3=\text { kekuatan yang besar } & 2=\text { kelemahan yang cukup } \\ 4=\text { kekuatan yang sangat besar } & \text { berarti } \\ & 3=\text { kelemahan yang kurang } \\ & \text { berarti } \\ & 4=\text { kelemahan yang tidak berarti }\end{array}$

Untuk matriks EFAS, skala nilai peringkat (rating) untuk peluang dan ancaman yang digunakan adalah sebagai berikut.

Tabel 2. Matriks EFAS

$\begin{array}{ll}1=\text { peluang yang kecil } & 1=\text { ancamana yang sangat besar } \\ 2=\text { peluang yang sedang } & 2=\text { ancaman yang cukup besar } \\ 3=\text { peluang yang besar } & 3=\text { ancaman yang sedang } \\ 4=\text { peluang yang sangat } & 4=\text { ancaman yang kecil }\end{array}$

besar

\section{Teknik Pembobotan}

Faktor internal dan eksternal perusahaan dibuat terlebih dahulu. Penentuan bobot dilakukan dengan cara mengajukan identifikasi faktor strategis internal dan eksternal kepada pihak manajemen dengan menggunakan metode Pairwise Comparasion (David, 2006). Metode ini digunakan untuk memberikan penilaian terhadap bobot setiap faktor penentu internal dan eksternal perusahaan. Skala yang digunakan untuk pengisian kolom adalah:

Nilai 1: jika indikator horizontal kurang penting daripada indikator vertikal

Nilai 2: jika indikator horizontal sama penting dengan indikator vertikal

Nilai 3: jika indikator lebih penting daripada indikator vertikal

\section{Analisis Matriks IFAS dan EFAS}

Menurut David (2006), untuk mendapatkan matriks IFAS maupun EFAS dengan mengalikan nilai bobot dengan nilai rating yang ada. 
Tabel 3. Teknik Pembobotan

\begin{tabular}{|c|c|c|c|}
\hline Faktor Internal / Faktor Eksternal & Bobot & Rating & Bobot $\mathrm{x}$ rating( skor) \\
\hline \multicolumn{4}{|l|}{ Kekuatan / Peluang } \\
\hline \multicolumn{4}{|l|}{1.} \\
\hline \multicolumn{4}{|l|}{2.} \\
\hline \multicolumn{4}{|l|}{-} \\
\hline \multicolumn{4}{|l|}{ Kelemahan / Ancaman } \\
\hline \multicolumn{4}{|l|}{1.} \\
\hline \multicolumn{4}{|l|}{2.} \\
\hline \multicolumn{4}{|l|}{-} \\
\hline Total & 1,0 & & \\
\hline
\end{tabular}

\section{Strategi Pemasaran Jamur Tiram}

Setelah semua faktor internal dan faktor eksternal diketahui, maka selanjutnya dapat diketahui kondisi atau keadaan usaha pemasaran jamur tiram di Kota Mataram dengan menggunakan Analisis SWOT.

Gabungan matriks IFAS dan EFAS menghasilkan diagram analisis SWOT yang berisi strategi yang terkait dengan faktor internal dan faktor eksternal yang memperlihatkan kombinasi total nilai bobot dari matriks-matriks IFE dan EFE (Septiadi \& Mundiyah, 2020). Tujuan penggunaan matriks ini untuk memperoleh strategi bisnis di tingkat unit bisnis yang lebih detail.

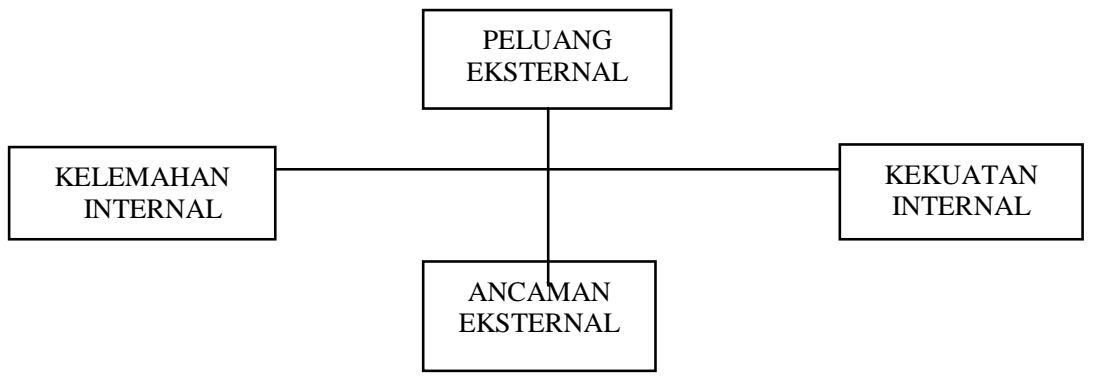

Gambar 1. Analisis SWOT

\section{Analisis Matriks SWOT}

Matriks ini menggambarkan secara jelas bagaimana peluang dan ancaman dapat disesuaikan dengan kekuatan dan kelemahan. Matrik SWOT merupakan alat pencocokan yang penting yang membantu manajer mengembangkan empat tipe strategi: Strategi SO, Strategi WO, Strategi ST, Strategi WT. Mencocokkan faktor eksternal dan internal kunci merupakan bagian sulit terbesar untuk mengembangkan Matriks SWOT dan memerlukan penilaian yang baik, dan tidak ada satu pun kecocokan terbaik (David, 2006). 
Tabel 4. Matriks SWOT :

\begin{tabular}{|c|c|c|}
\hline IFAS & Kekuatan (S) & Kelemahan (W) \\
\hline EFAS & Daftar kekuatan & Daftar kelemahan \\
\hline Peluang $(\mathrm{O})$ & $\underline{\text { Strategi S-O }}$ & Strategi W-O \\
\hline Daftar kekuatan-peluang & $\begin{array}{l}\text { Membuat strategi dengan } \\
\text { menggunakan kekuatan } \\
\text { untuk memanfaatkan } \\
\text { peluang }\end{array}$ & $\begin{array}{l}\text { Membuat strategi yang } \\
\text { memanfaatkan peluang } \\
\text { untuk mengatasi kelemahan }\end{array}$ \\
\hline Ancal & Strategi S-T & Strategi W-T \\
\hline Daftar kelemahan-ancaman & $\begin{array}{l}\text { Membuat strategi yang } \\
\text { menggunakan kekuatan } \\
\text { untuk menghindari ancaman }\end{array}$ & $\begin{array}{l}\text { Membuat strategi yang } \\
\text { meminimumkan kelemahan } \\
\text { dan menghindari ancaman }\end{array}$ \\
\hline
\end{tabular}

\section{Penentuan Strategi Prioritas}

QSPM Quantitative Strategic Planning Matrix (QSPM) merupakan pendekatan yang dilakukan setelah mendapatkan skor pembobotan dari SWOT, untuk mendapatkan prioritas strategi alternatif yang akan dinilai menggunakan skor kemenarikan. Secara spesifikasi nilai daya tarik harus diberikan pada setiap strategi untuk menunjukkan daya tarik relatif dari satu strategi atas strategi yang lain dengan mempertimbangkan faktor tertentu. Nilai daya tarik itu adalah :

Nilai $1=$ Tidak Menarik

Nilai 3 = Cukup Menarik

Nilai $2=$ Agak Menarik

Nilai $4=$ Sangat Menarik

\section{HASIL DAN PEMBAHASAN}

\section{Karakteristik Responden}

Karakteristik responden merupakan bagian yang terpenting dari suatu penelitian karena untuk mengetahui keadaan masing-masing responden tersebut. Karakteristik tersebut terdiri dari umur responden, tingkat pendidikan, jumlah tanggungan keluarga, dan pengalaman berusaha.

\section{Umur Responden}

Umur responden sangat berpengaruh terhadap produktivitas usaha, kemampuan merespon segala permasalahan dan dalam menyerap informasi serta penerapan inovasi baru. Semakin lanjut usia responden maka produktivitas semakin menurun karena dalam berusaha membutuhkan fisik yang prima. Sebaliknya, semakin muda umurnya maka kemampuan dalam bekerja akan semakin produktif dan memiliki semangat yang tinggi (Prayitno, 1987). Berikut data umur responden petani jamur tiram di Kota Mataram tahun 2020 dapat dilihat pada Tabel 4.4. 
Tabel 5. Umur Responden Petani dan Pedagang Pengecer Jamur Tiram di Kota Mataram

\begin{tabular}{crrrr}
\hline \multirow{2}{*}{$\begin{array}{l}\text { Kisaran Umur } \\
\text { Responden (Umur) }\end{array}$} & $\begin{array}{r}\text { Jumlah } \\
(\text { Org) }\end{array}$ & $\begin{array}{r}\text { Persentase } \\
(\%)\end{array}$ & $\begin{array}{r}\text { Jumlah } \\
(\text { Org })\end{array}$ & $\begin{array}{r}\text { Persentase } \\
(\%)\end{array}$ \\
\hline a. $15-26$ & 5 & 26,32 & 0 & 0 \\
b. $27-37$ & 6 & 31,58 & 1 & 50,00 \\
c. $38-48$ & 4 & 21,05 & 1 & 50,00 \\
d. $49-59$ & 4 & 21,05 & 0 & 0 \\
\hline JUMLAH & 19 & 100 & 2 & 100 \\
\hline
\end{tabular}

Sumber: Data Primer Diolah (2020)

Pada tabel 4.4 dapat dilihat bahwa kisaran umur petani 21-30 tahun sebanyak 5 orang (26,32\%), umur 31-40 tahun sebanyak 6 orang $(31,58)$, umur 41-50 tahun sebanyak 4 orang $(21,05 \%)$, dan umur 51-60 tahun sebanyak 4 orang $(21,05 \%)$. Dan kisaran umur pedagang pengecer kisarab umur 27-37 tahun sebanyak 1 orang (50\%) dan kisaran 38-48 tahun sebanyak 1 orang $(50 \%)$. Hal ini menunjukkan bahwa rata-rata umur responden yaitu 38 tahun dengan kisaran umur antara 21-60 tahun dimana merupakan usia produktif, artinya secara mental mempunyai kemampuan untuk bekerja dan berusaha secara fisik maupun mental dalam melakukan kegaiatan usahanya untuk memperoleh hasil produksi yang maksimal terutama dalam memasarkan jamur tiram. Hal tersebut didukung oleh pendapat (Simanjuntak, 1985) yang menyatakan bahwa golongan umur produktif berkisar antara 1564 tahun dan dianggap mampu untuk bekerja.

\section{Tingkat Pendidikan}

Tingkat pendidikan responden merupakan salah satu penentu penting karena pendidikan akan mempengaruhi kemampuan dalam menyerap informasi, kemampuan dalam mengelola manajemen usaha dan kemampuan dalam penguasaan strategi pemasaran. Sehingga semakin tinggi tingkat pendidikan seseorang maka wawasan atau pola pikirnya akan semakin baik dan rasional dalam melakukan kegiatan usaha dan mampu memilih alternative terbaik. Sebaliknya, semakin rendah tingkat pendidikan seseorang maka akan sulit untuk menyerap informasi, kemampuan dalam mengelola manajemen usaha dan kemampuan dalam penguasaan strategi pemasaran. Tingkat pendidikan responden petani jamur tiram di Kota Mataram dapat dilihat pada Tabel 6 berikut.

Tabel 6. Tingkat Pendidikan Responden Petani dan Pedagang Pengecer Jamur Tiram di Kota Mataram Tahun 2020

\begin{tabular}{lcccc}
\hline & \multicolumn{2}{c}{ Petani } & \multicolumn{2}{c}{ Pedagang Pengecer } \\
\cline { 2 - 5 } Kisaran Umur Responden (Umur) & $\begin{array}{c}\text { Jumlah } \\
(\text { Org })\end{array}$ & $\begin{array}{c}\text { Persentase } \\
(\%)\end{array}$ & $\begin{array}{c}\text { Jumlah } \\
(\text { Org })\end{array}$ & $\begin{array}{c}\text { Persentase } \\
(\%)\end{array}$ \\
\hline a. Tidak Tamat SD & - & - & - & - \\
b. Tamat SD & 6 & 31,58 & - & - \\
c. Tidak Tamat SMP & - & - & - & - \\
d. Tamat SMP & 2 & 10,53 & - & - \\
e. Tidak Tamat SMA & - & - & - & - \\
f. Tamat SMA & 7 & 36,84 & 2 & 100
\end{tabular}

Nuraini, U., Sukardi, L., dan Efendy 


\begin{tabular}{lcccc}
\hline \multirow{2}{*}{ Kisaran Umur Responden (Umur) } & \multicolumn{2}{c}{ Petani } & \multicolumn{2}{c}{ Pedagang Pengecer } \\
\cline { 2 - 5 } & $\begin{array}{c}\text { Jumlah } \\
(\text { Org })\end{array}$ & $\begin{array}{c}\text { Persentase } \\
(\%)\end{array}$ & $\begin{array}{c}\text { Jumlah } \\
(\text { Org })\end{array}$ & $\begin{array}{c}\text { Persentase } \\
(\%)\end{array}$ \\
\hline g. Perguruan Tinggi & 4 & 21,05 & - & - \\
\hline JUMLAH & 19 & 100 & 2 & 100 \\
\hline
\end{tabular}

Sumber: Data Primer Diolah (2020)

Berdasarkan Tabel 6 bahwa rata-rata petani jamur tiram di Kota Mataram pernah mengikuti kegiatan pendidikan formal. Tingkat pendidikan Tamat Sekolah Menengah Atas (SMA) merupakan tingkat pendidikan terbanyak yang pernah ditempuh oleh petani jamur tiram yaitu sebanyak 7 orang, sementara tingkat pendidikan Tamat Sekolah Dasar (SD) yaitu sebanyak 6 orang, Tamat Sekolah Menengah Pertama (SMP) sebanyak 2 orang, dan tingkat pendidikan yang paling tinggi adalah Perguruan Tinggi sebanyak 4 orang dan tingkat pendidikan pedang pengecer adalah tamat SMA sebanyak 2 orang. Artinya tingkat pendidikan petani jamur tiram dan pedagang pengecer jamur tiram di Kota Mataram ini tergolong cukup yang dapat diandalkan dalam proses kegiatan usaha yang dilakukan.

\section{Pengalaman Usaha}

Pengalaman usaha berpengaruh pada keahlian berusaha jamur tiram. Pengalaman berusaha merupakan lamanaya petani jamur tiram dalam menjalankan usaha jamur tiram. Petani yang mempunyai banyak pengalaman berusaha akan lebih ahli dan handal dalam mengelola kegiatan usaha atau sebaliknya jika petani jamur tiram kurang cukup pengalaman akan mengalami kesulitan dalam menentukan langkah-langkah dan keputusankeputusan yang harus diambil dalam menjalankan usaha. Lama pengalaman berusaha responden dapat dilihat pada Tabel 7.

Tabel 7. Pengalaman Berusaha Petani dan Pedagang Pengecer Jamur Tiram di Kota Mataram Tahun 2020

\begin{tabular}{lrrrr}
\hline \multirow{2}{*}{ Pengalaman Berusaha } & Petani & \multicolumn{3}{c}{ Pedagang Pengecer } \\
\cline { 2 - 5 } & $\begin{array}{c}\text { Jumlah } \\
(\text { Org })\end{array}$ & $\begin{array}{c}\text { Persentase } \\
(\%)\end{array}$ & $\begin{array}{c}\text { Jumlah } \\
(\text { Org })\end{array}$ & $\begin{array}{c}\text { Persentase } \\
(\%)\end{array}$ \\
\hline a. $2-3$ & 13 & 68,42 & 2 & 100 \\
b. $4-5$ & 5 & 26.32 & - & - \\
c. $6-7$ & 1 & 5,26 & - & - \\
\hline JUMLAH & 19 & 100 & 2 & 100 \\
\hline
\end{tabular}

Sumber: Data Primer Diolah (2020)

Berdasarkan tabel 4.6 bahwa pengalaman berusaha petani jamur tiram pada kisaran pengalaman 2-3 tahun sebanyak 13 orang $(68,42 \%)$, umur 4-5 tahun sebanyak 5 orang (26,32\%), pengalaman 6-7 tahun tahun 1 orang $(5,26 \%)$ dan pengalaman berusaha pedang pengecer 2-3 tahun sebanyak 2 orang (100\%). Hasil penelitian menunjukkan bahwa ratarata petani jamur tiram di Kota Mataram memiliki pengalaman yang tergolong usaha baru. Dengan demikian maka dari segi pengalaman tentunya perlu kehati-hatian terhadap segala kemungkinan yang terjadi, dan tentunya lebih bijak dalam mengambil keputusan dengan segala tingkat risiko yang akan terjadi. 


\section{Tanggungan Keluarga}

Besar kecilnya angota rumah tangga akan mempengaruhi besar kecilnya jumlah tanggungan keluarga. Semakin banyak anggota keluarga akan memberikan gambaran tentang jumlah pengeluaran per kapita per tahun, per bulan, per hari. Semakin banyak anggota keluarga semakin besar tanggungan keluarga. Jumlah tanggungan keluarga petani responden dapat dilihat pada Tabel 8 berikut.

Tabel 8. Jumlah Tanggungan Keluarga Responden Petani dan Pedagang Pengecer Jamur Tiram di Kota Mataram Tahun 2020

\begin{tabular}{lrcrr}
\hline & \multicolumn{3}{c}{ Petani } & \multicolumn{3}{c}{ Pedagang Pengecer } \\
\cline { 2 - 5 } Jumlah Tanggungan & $\begin{array}{c}\text { Jumlah } \\
(\text { Org })\end{array}$ & Persentase $(\%)$ & $\begin{array}{c}\text { Jumlah } \\
(\text { Org })\end{array}$ & $\begin{array}{c}\text { Persentase } \\
(\%)\end{array}$ \\
\hline a. $1-2$ & 11 & 57,90 & 1 & 50 \\
b. $3-4$ & 7 & 36,84 & 1 & 50 \\
c. $5-6$ & 1 & 5,26 & - & - \\
\hline JUMLAH & 19 & 100 & 2 & 100 \\
\hline
\end{tabular}

Sumber: Data Primer Diolah (2020)

Tabel 8 menunjukkan bahwa jumlah anggota keluarga petani pada kisaran 1-2 sebanyak 11 orang dan sementara pada kisaran 3-4 sebanyak 7 orang dan kisaran 5-6 sebanyak 1 orang tanggungan keluarga dan pedagang pengecer jumlah tanggungan kisaran 1-2 tahun sebanyak 1 orang (50\%) dan kisaran 3-4 sebanyak 1 orang (50\%). Kondisi ini menunjukkan bahwa rata-rata jumlah anggota keluarga responden merupakan keluarga menengah. Hal ini sesuai dengan pendapat Ilyas (1998) bahwa besar kecilnya jumlah anggota keluarga tergantung dari jumlah anggota keluarga yang ditanggung. Keluarga tergolong kecil apabila mempunyai tanggungan antara 1-2 orang, keluarga menengah mempunyai tanggungan keluarga 3-4 orang dan keluarga besar jika tanggungan 5-6 orang.

\section{Saluran Pemasaran Jamur Tiram di Kota Mataram}

Dari hasil penelitian saluran pemasaran jamur tiram di Kota Mataram terdapat dua saluran, yaitu:

a) Saluran PemasaranI :Produsen - Konsumen Akhir

b) Saluran PemasaranII :Produsen - PedagangPengecer - KonsumenAkhir

1) Saluran Pemasaran I (Petani - Konsumen Akhir)

Proses pemasaran jamur tiram pada saluran I, petani langsung menjual produk jamur tiram ke konsumen akhir dengan melakukan kemasan dan harga yang berbeda tiap kemasannya. Adapun ukuran dan harga jamur tiram yang dijual ke konsumen akhir yaitu kemasan 1 ons dengan harga rata-rata Rp 4.000, kemasan 1,5 ons dengan harga rata-rata Rp 4.882, kemasan 250 gram dengan harga rata-rata Rp 6.382 dan emasan $1 \mathrm{~kg}$ dengan harga rata-rata Rp 27.647. Dalam proses pemasaran yang dilakukan petani mengantarkan hasil produksi ke konsumen akhir, daerah pemasaran jamur tiram hanya berkisar pada daerah produksi untuk petani jamur tiram yang berada di Kecamatan Ampenan menjual jamur tiramnya di Pasar ACC dan Pasar Kebon Roek dan petani jamur tiram yang berada di Kecamatan Pagutan menjual jamur tiram di Pasar Pagutan.

2) Saluran Pemasaran II (Petani - Pedagang pengecer - Konsumen Akhir)

Proses pemasaran jamur tiram pada saluran II, melibatkan satu lembaga pemasaran yaitu pedagang pengecer. Terdapat 2 petani yang menjual hasil produksi ke pedagang

Nuraini, U., Sukardi, L., dan Efendy 
pengecer. Pedagang pengecer pada saluran II adalah sebanyak 2 orang. Pedagang pengecer melakukan pembelian secara langsung kepada petani, volume beli 6-8 kg dengan harga beli rata-rata $\mathrm{Rp} 20.000 / \mathrm{Kg}$ yang nantinya pedagang pengecer akan menjual ke konsumen akhir dengan harga jual rata-rata $\mathrm{Rp} 25.000 / \mathrm{kg}$ dan dengan biaya pemasaran transportasi rata-rata Rp 8.500, dan biaya pemasaran transportasi ditanggung oleh pedagang pengecer. Temuan ini didukung penelitian Meitasari (2011), yang menyimpulkan bahwa jumlah lembaga pemasaran jamur tiram mempengaruhi tingkat pendapatan petani. Semakin panjang jalur pemasaran, maka biaya pemasaran makin tinggi.

\section{Faktor Internal dan Faktor Eksternal Pemasaran Jamur Tiram}

Faktor-faktor yang mempengaruhi pemasaran jamur tiram di Kota Mataram terdiri dari faktor internal (kekuatan dan kelemahan) dan eksternal (peluang dan ancaman). Faktor ini memiliki pengaruh terhadap keberhasilan atau kegagalan dalam produksi dan pemasaran jamur tiram. Hasil identifikasi faktor-faktor yang mempengaruhi dijelaskan sebagai berikut:

\section{Faktor Internal (Kekuatan dan Kelemahan) Pemasaran Jamur Tiram a. Kekuatan}

Hasil penelitian menunjukkan kekuatan pemasaran jamur tiram terdiri dari:

1. Kualitas jamur tiram yang baik

Menurut Sukanteri (2020), produk yang berkualitas dapat dilihat dari beberapa indikator salah satunya performance produk tersebut. Dalam penelitian ini, produk jamur tiram yang dihasilkan petani responden temasuk memiliki kualitas yang baik. Hal tersebut dapat dilihat dari warna jamur tiram yang putih bersih, tekstur yang tegar dan rapuh, dan aroma khas jamur tiram kurang kuat. Sedangkan untuk jamur tiram yang kurang baik yaitu berwarna kuning-kecoklatan, tekstur sangat lunak dan berair, dan aroma khas jamur tiram sangat kuat.

2. Besarnya modal yang cukup

Berdasarkan hasil wawancara dengan petani jamur tiram, rata-rata modal dari usaha jamur tiram (Lampiran 5) sebesar Rp 9.526.316 dengan modal usaha terendah sebesar Rp 3.000.000 dan modal tertinggi sebesar Rp 50.000.000. Hal ini memberikan kekuatan bagi petani jamur tiramdikarenakan memiliki modal yang tersedia untuk mengembangkan usaha jamurtiram putih. Dalam memulai suatu usaha jamur tiram tidak harus menyediakan modal yang besar dikarenakan modal yang dibutukan dapat disesuaikan skala usaha yang akandijalakan.

3. Penetapan harga yang terjangkau oleh konsumen

Berdasarkan hasil wawancara dengan petani jamur tiram, rata-rata harga jual jamur tiram adalah $\mathrm{Rp} 25.000 / \mathrm{kg}$ dengan rentang harga antara $\mathrm{Rp} 20.000-\mathrm{Rp} 30.000 / \mathrm{kg}$. Hal ini menjadi kekuatan usaha jamur tiram karena harga jual yang diberikan petani relatif terjangkau bila dibangdingkan dengan harga jamur kuping/hitam kering dengan harga Rp $75.500 / \mathrm{Kg}$.

4.. Kontinuitas produksi

Kontinuitas produksi salah satu kekuatan usaha jamur tiram. Upaya yang dilakukan petani jamur tiram untuk menjaga kontinuitas produksi dengan cara melakukan penanaman secara berkala yaitu menanam jamur tiram berbeda bulan \pm 1 bulan untuk mencukupi 
kebutuhuan pasar sehingga setiap pengecer atau konsumen memerlukan jamur tiram, jamur tiram siap di dipanen dan tetap dalam kualitas jamur tiram yang baik.

\section{b. Kelemahan}

\section{Produk jamur tiram cepat rusak}

Kualitas produk jamur tiram yang dihasilkan oleh petani jamur tiram memiliki kualitas produk yang baik tetapi daya simpan pasca panen dari jamur tiram hanya bisa bertahan dua sampai empat hari. Hal tersebut dikarenakan, jamur tiram sangat aktif melepaskan uap air, sehingga jamur tiram menjadi kering dan kantong penyimpanan menjadi basah karena uap air. Basahnya kantong penyimpanan bisa menyebabkan jamur tiram menjadi lebih cepat busuk dan tidak bisa digunakan kembali. Sedangkan jika jamur tiram kering warnanya menjadi kekuningan.

2. Jangkauan pasar hanya terbatas pasar lokal

Daerah pemasaran jamur tiram saat ini masih sangat terbatas di sekitar daerah produksi dan pasar lokal sekitar daerah produksi. Banyak jangkauan pemasaran yang belum di masuki oleh petani jamur tiram misalnya dengan memanfaatkan perkembangan teknologi informasi melalui pemasaran secara online dan pasar modern seperti supermarketmaka hal tersebut menjadi kelemahan pemasaran jamur tiram saat ini.

3. Bentuk produk yang dijual gelondongan

Petani jamur tiram menjual produk ke pedagang pengecer dalam bentuk gelondong hal ini merupakan ancaman bagi petani jika petani menjual hasil dalam bentuk gelondongan akan membuat ukuran yang tidak pasti dan kemungkinan terjadi kerugian pada harga yaitu harga yang dijual dalambentuk gelondongan lebih rendah bila dibandingkan dengan harga jamur tiram yang sudah dikemas. Secara ringkas faktor kekuatan dan kelemahan disarankan dalam Tabel 9. Dalam tabel disajikan juga hasil penilaian masing-masing faktor dan komentar terhadap masing-masing faktor.

Tabel 9. Matriks Faktor Internal Pemasaran Jamur Tiram di Kota Mataram

\begin{tabular}{|c|c|c|c|c|}
\hline \multirow{2}{*}{ Faktor Strategi Internal } & \multicolumn{3}{|c|}{ Penilaian } & \multirow{2}{*}{ Keterangan } \\
\hline & Bobot & Rating & Skor & \\
\hline \multicolumn{5}{|l|}{ Kekuatan } \\
\hline a. Kualitas jamur tiram yang baik & 0,171 & 4 & 0,684 & $\begin{array}{l}\text { Dipetahankan } \\
\text { dan dijaga }\end{array}$ \\
\hline b. Besarnya modal yang cukup & 0,154 & 3 & 0,462 & Dipertahankan \\
\hline $\begin{array}{l}\text { c. Penetapan harga yang } \\
\text { terjangkau oleh konsumen }\end{array}$ & 0,161 & 3 & 0,483 & Dipertahankan \\
\hline d. Kontinuitas produksi & 0,165 & 4 & 0,660 & Dipertahankan \\
\hline Total & 0,651 & & 2,289 & \\
\hline \multicolumn{5}{|l|}{ Kelemahan } \\
\hline e. Produk jamur tiram cepat rusak & 0,125 & 3 & 0,375 & Dioptimalkan \\
\hline $\begin{array}{l}\text { f. Jangkauan pasar hanya terbatas } \\
\text { pada pasar local }\end{array}$ & 0,108 & 2 & 0,216 & Dioptimalkan \\
\hline
\end{tabular}

Nuraini, U., Sukardi, L., dan Efendy 


\begin{tabular}{lcccc}
$\begin{array}{l}\text { g. Bentuk produk yang dijual } \\
\text { gelondongan }\end{array}$ & 0,116 & 2 & 0,232 & Dioptimalkan \\
Total & 0,349 & & 0,823 & \\
\hline Total Faktor Strategi Internal & 1,000 & & 1,466 & \\
\hline
\end{tabular}

Sumber: Data Primer Diolah (2020)

Hasil analisis Tabel 9 dapat dilihat bahwa total skor pembobotan faktor internal sebesar 1,466 yang diperoleh dari selisih antara total skor faktor kekuatan sebesar 2,289 dan total skor kelemahan sebesar 0,823 . Total skor faktor kekuatan dan kelemahan diperoleh dari jumlah hasil perkalian antara bobot dan rating dari masing-masing faktor. Dari hasil tersebut dapat disimpulkan bahwa usaha pemasaran jamur tiram di Kota Mataram berada pada posisi kuat, dimana kekuatan yang dimiliki dapat menutupi kelemahan yang ada.

\section{Faktor Eksternal (Peluang dan Ancaman) Pemasaran Jamur Tiram}

\section{a. Peluang}

1. Jamur tiram dapat diolah menjadi produk turunan

Petani jamur tiram mempunyai peluang untuk menjual hasil produk tidak hanya jamur tiram segar tetapi bisa dalam berbagai hasil olahan jamur tiram segar misalnya dengan menjual makanan olahan jamur tiram seperti sate jamur, crispy jamur,jamur goreng, sop jamur, bumbu penyedap jamur, tongseng jamu, dan lain-lain yang nantinya akan meningkatkan nilai tambah dari jamur tiram segar (Mundiyah et al., 2020).

2. Perkembangan pasar online dan pasar modern

Perkembangan teknologi informasi sangat pesat memberikan manfaat terbukanyajangkauan pemasaran yang lebih luas seperti pasar online dan pasar modern.lain pemasaran secara online jangkauan pemasaran juga dapat dilakukan di pasar modern seperti minimarket, supermarket, hypermarket yang berkembang secara pesat. Peluang tersebut dapat dimanfaatkan oleh petani jamur tiram untuk memasarkan hasil produknya.Dalam pemanfaatan peluang tersebut petani jamur tiram juga harus mampu untuk meningkatkan mutu produk dan melakukan inovasi-inovasi hasil produksi sesuai standar kualitas mutu sehingga produk jamur tiram dapat bersaing pasar online dan pasar modern.

3. Dukungan kebijakan pemerintah

Kebijakan pemerintah untuk mengembangkan usaha mikro, kecil dan menengah (UMKM) melalui pemberian bantuan modal kepada UMKM melalui program Kredit UsahaRakyat (KUR), dukungan dalam bentuk pemberianpengarahan dan pembinaan dalam hal pembudidayaan jamur tiram mulai dari kegiatan produksi sampai pemasaran produk serta pemberianbantuan peralatan dan informasi-informasi mengenai seminar yang dapat menambahketerampilan petani jamur tiram. Dengan adanya dukungan dari pemerintah tersebut dapat dijadikan sebagai peluang untuk meningkatkan usaha jamur tiram.

Sebagai perbandingan dan pendukung dari temuan penelitian berupa tiga faktor peluang tersebut diatas, menurut Marini et al, (2019) faktor - faktor yang menjadi peluang adalah luasnya pangsa pasar, daya beli masyarakat tinggi, adanya intervensi pemerintah, permintaan produk jamur tiram semakin meningkat, serta kemajuan teknologi. 


\section{b. Ancaman}

1. Masuknya produk sejenis dari daerah lain

Kota Mataram bukan satu-satunya daerah yang menghasilkan jamur tiram terdapat daerah lain yang yang menghasilkan jamur tiram. Berdasarkan BPS Tanaman Sayuran dan Buahbuahan Semusim (2018) data produksi tertinggi yaitu di wilayah Jawa Barat produksi jamur tiram sebesar 16.692.355 Kg dan Jawa Timur 8.071.803 Kg. Hal tersebut menunjukkan bahwa tidak menutup kemungkinan hasil produksi jamur tiram dari Pulau Jawa masuk ke Kota Mataram.

2. Berkembangnya produk substitusi

Produk jamur tiram segar dapat dijadikan sebagai makanan yangdikonsumsi setiap hari. Namun demikian, terdapat produk substitusi dari kelompok sayuran lainnya yang dapatdijadikan sebagai makanan alternative seperti wortel dan bayam. Dua jenisproduk tersebut merupakan produk substitusi dari produk jamur tiram. Karenakondisi produk substistusi tersebut lebih dikenal oleh masyarakat sehingga keberadaanyadapat lebih menguasai pasar dibanding produk jamur tiram. Oleh karena itu, adanyaproduk substitusi ini menjadi ancaman bagi petani jamur tiram dalam memasarkanproduknya.

Secara ringkas faktor peluang dan ancaman disarankan pada Tabel 10. Dalam tabel disajikan juga hasil penilaian masing-masing faktor dan komentar terhadap masing-masing faktor.

Tabel 10. Matriks Faktor Eksternal Pemasaran Jamur Tiram di Kota Mataram

\begin{tabular}{|c|c|c|c|c|}
\hline \multirow{2}{*}{ Faktor Strategi Eksternal } & \multicolumn{3}{|c|}{ Penilaian } & \multirow{2}{*}{ Keterangan } \\
\hline & Bobot & Rating & Skor & \\
\hline \multicolumn{5}{|l|}{ Peluang } \\
\hline $\begin{array}{l}\text { a. Jamur tiram dapat diolah menjadi produk } \\
\text { turunan }\end{array}$ & 0,223 & 3 & 0,669 & Dipertahankan \\
\hline $\begin{array}{l}\text { b. Perkembangan pasar online dan pasar } \\
\text { modern }\end{array}$ & 0,220 & 4 & 0,880 & Dipertahankan \\
\hline c. Dukungan kebijakan pemerintah & 0,172 & 3 & 0,516 & Dipertahankan \\
\hline Total & 0,615 & & 2,065 & \\
\hline \multicolumn{5}{|l|}{ Ancaman } \\
\hline d. Masuknya produk sejenis dari daerah lain & 0,175 & 2 & 0,350 & $\begin{array}{l}\text { Disediakan } \\
\text { altenatif }\end{array}$ \\
\hline e. Berkembangnya produk substitusi & 0,210 & 3 & 0,630 & $\begin{array}{l}\text { Disediakan } \\
\text { altenatif }\end{array}$ \\
\hline Total & 0,385 & & 0,980 & \\
\hline Total Strategi Eksternal & 1,000 & & 1,085 & \\
\hline
\end{tabular}

Sumber: Data Primer Diolah (2020)

Hasil analisis Tabel 10 di atas dapat dilihat bahwa total skor pembobotan faktor eksternal sebesar 1,085 yang diperoleh dari selisih total skor faktor peluang 2,065 dan skor ancaman sebesar 0,980. Total skor faktor peluang dan ancaman diperoleh jumlah hasil perkalian antara bobot dan rating dari masing-masing faktor. Dari hasil tersebut dapat disimpulkan bahwa usaha pemasaran jamur tiram di Kota Mataram berada pada posisi kuat, 
dimana peluang yang dimiliki sudah dimanfaatkan secara optimal untuk mengatasi ancaman yang ada.

\section{Strategi Pemasaran Jamur Tiram}

Setelah semua faktor internal dan eksternal diketahui, maka selanjutnya dapat diketahui kondisi atau keadaan usaha pemasaran jamur tiram di Kota Mataram. Berdasarkan hasil analisis kondisi usaha berada pada Kuadran I yaitu strategipertumbuhan agresif (Growth oriented strategy). Strategi ini menunjukkan situasi yang menguntungkan bagi petani jamur tiram. Pemasaran jamur tiram di Kota Mataram memiliki peluang dan kekuatan yang saling mendukung sehingga dapat memanfaatkan peluang yang ada. Menurut Rangkuti (2013) usaha pada posisi ini menghadapi pertumbuhan besar yang sangat cepat dan pangsa pasar yang sangat besar. Usaha ini memerlukan investasi untuk memperkuat posisi dominannya di dalam pasar yang sedang tumbuh. Artinya, usaha jamur tiram pada kondisi saat ini sangat memerlukan modal untuk dapat bertumbuh sehingga produksi jamur tiram dapat ditingkatan dan memenuhi kebutuhan pasar.

Hasil evaluasi faktor internal dan evaluasi faktor eksternal kemudian dianalisis dengan Matriks SWOT untuk menetukan alternative startegi pemasaran jamur tiram di Kota Mataram. Hasil matriks

Tabel 11. Matriks SWOT

IFAS STRENGTH (S) WEAKNESS (W)

1. Kualitas jamur tiram yang 1. Produk jamur tiram cepat baik rusak

2. Besarnya modal yang 2. Jangkauan pasar hanya terjangkau terbatas pasar lokal

3. Penetapan harga yang 3. Bentuk produk yang terjangkau oleh konsumen dijual dalam bentuk

EFAS

4. Kontinuitas produksi gelondongan

\begin{tabular}{|c|c|c|}
\hline OPPORTUNITIES(O) & STRATEGI (SO) & STRATEGI (WO) \\
\hline $\begin{array}{l}\text { 1. Jamur tiram dapat } \\
\text { diolah menjadi } \\
\text { produk turunan }\end{array}$ & $\begin{array}{l}\text { 1. Menjaga dan } \\
\text { meningkatkan kualitas } \\
\text { produk (S1,S4, O2). }\end{array}$ & $\begin{array}{l}\text { 1. Meningkatkan promosi } \\
\text { jamur tiran (W2, O2,O3). } \\
\text { 2. Melakukan pengemasan }\end{array}$ \\
\hline $\begin{array}{l}\text { 2. Perkembangan pasar } \\
\text { online dan pasar } \\
\text { modern }\end{array}$ & $\begin{array}{l}\text { 2. Meningkatkan nilai } \\
\text { tambah dengan melakukan } \\
\text { pengolahan produk dari }\end{array}$ & $\begin{array}{l}\text { dalam berbagai ukuran } \\
(\mathrm{W} 3, \mathrm{O} 2, \mathrm{O} 3)\end{array}$ \\
\hline $\begin{array}{l}\text { 3. Dukungan kebijakan } \\
\text { pemerintah }\end{array}$ & $\begin{array}{l}\text { jamur tiram segar (S1, O1, } \\
\text { O2). }\end{array}$ & \\
\hline THREAT (T) & STRATEGI (ST) & STRATEGI (WT) \\
\hline $\begin{array}{l}\text { 1. Masuknya produk } \\
\text { sejenis dari daerah } \\
\text { lain }\end{array}$ & $\begin{array}{l}\text { 1. Memperluas jaringan } \\
\text { pemasaran }(\mathrm{S} 1, \mathrm{~S} 4, \mathrm{~T} 1)\end{array}$ & $\begin{array}{l}\text { 1. Memperluas } \\
\text { aksesinformasi pasar } \\
\text { dengan penggunaan }\end{array}$ \\
\hline $\begin{array}{l}\text { 2. Berkembangnya } \\
\text { produk substitusi }\end{array}$ & & $\begin{array}{l}\text { teknologi informasi } \\
\text { (W1,W2.T1) }\end{array}$ \\
\hline
\end{tabular}

Nuraini, U., Sukardi, L., dan Efendy 


\section{Matriks SWOT}

Berdasarkan kekuatan, kelemahan, peluang dan ancaman yang diperoleh melalui matriks IFAS dan EFAS, maka dapat dirumuskan beberapa alternatif strategi yang dapat diterapkan oleh petani jamur tiram dalam upaya pemasaran serta pengembangan usaha dan menjaga kelangsungan usaha di tengah persaingan. Beberapa alternatif strategi yang dapat diterapkan adalah:

\section{Strategi S-O (Strengths-Opportunities)}

Strategi S-O merupakan strategi yang dapat diterapkan oleh petani jamur tiram yang menggunakan kekuatan internal untuk memanfaatkan peluang yang ada. Strategi S-O yang dapat diterapkan yaitu:

a) Menjaga dan meningkatkan kualitas produk

Strategi ini terkait dengan strategi bauran pemasaran tentang produk (product). Produk yang dihasilkan harus berkualitas baik. Petani jamur tiram harus mampu menjaga dan meningkatkan kualitas produk, upaya yang dapat dilakukan yaitu tidak mencoba menggunakan bahan-bahan kimia dalam melakukan proses produksi, baik untuk melakukan pemupukan maupun mengatasi hama penyakit. Hal itu dilakukan untuk menjaga agar produk yang dihasilkan aman untuk konsumen dan hasil produk jamur tiram sesuai dengan indikator tingkat kualitas jamur tiram yang baik. Sehingga dengan terus mempertahankan dan meningkatkan kualitas produk dapat memperluas pemasaranseperti memanfaatkan perkembangan pasar modern yang dimana untuk memasuki pasar modern memiliki ketentuan mutu produk untuk dapat dimasuki.

b) Melakukan pengolahan produk dari jamur tiram segar

Strategi ini ditempuh karena adanya kualias jamur tiram yang baik, perkembangan pasar online dan pasar modern. Dengan kekuatan yang dimiliki usaha jamur tiram yang selama ini dijual hanya berupa jamur tiram segar saja akan lebih bernilai ekonomis apabila dilakukan peningkatan kualitas dan jenis produk melalui proses pengolahan jamur tiram. Oleh sebab itu itu petani jamur tiram diharapkan dapat melalukan diversifikasi produk misalnya dengan menjual produk olahan seperti sate jamur, crispy jamur,jamur goreng, sop jamur, bumbu penyedap jamur, tongseng jamu, dan lain-lain. Pengolahan juga dilakukan untuk memvariatifkan produk sehingga produk yang dipasarkan tidak hanya dalam bentuk jamur tiram segar. Hal itu dapat lebih menarik banyak konsumen untuk membeliolahan produk segar jamur tiram dan sebagai salah satu upaya untuk meminimalisir kerugian akibat tidak terjualnya produk jamur tiram segar yang dipasarkan.

2. Strategi W-O (Weaknesses - Opportunities)

Strategi W-O adalah strategi yang ditujukan untuk mengatasi kelemahan dengan memanfaatkan peluang eksternal. Strategi yang diterapkan oleh petani jamur tiram adalah:

a) Meningkatkan promosi jamur tiram putih

Promosi yang dilakukan oleh petani jamur tiram saat ini masih dilakukan secara sederhana yaitu dengan cara mulut ke mulut. Sampai sejauh ini belum memanfaatkan teknologi informasi untuk melakukan kegiatan promosinya. Namun, saat ini peluang tersebut dapat dimanfaatkan dengan cara promosi melalui internet, iklan melalui koran ataupun majalah serta penyebaran brosur. Selain itu, mengikuti kegiatan yang diadakan oleh dinas atau pun lembaga yang berhubungan dengan usaha jamur tiram putih, dapat membantu memperlancar kegiatan promosi serta pemasaran produk jamur tiram. Dengan pemanfaatan media sosial dalam mempromosikan produk dapat memberikan peningkatan penjualan (Suparyana, 2020)

Nuraini, U., Sukardi, L., dan Efendy 
b) Melakukan pengemasan dengan berbagai ukuran

Strategi ini ditempuh untuk membidik pangsa pasar yang lebih luas dengan menawarkan kemasan dalam ukuran misalnya 200 gram, 250 gram, atau 500 gram untuk membidik konsumen rumah tangga, serta mengemas dalam ukuran $3 \mathrm{~kg}$ atau $5 \mathrm{~kg}$ untuk membidik para pelaku bisnis kuliner maupun industri lainnya yang membutuhkan jamur tiram. Selain untuk membidik pangsa pasar yang lebih luas, penggunaan kemasan juga penting untuk menjaga kesegaran jamur tiram.

3. Strategi S-T (Strengths - Threaths)

Strategi S-T adalah strategi yang menggunakan kekuatan perusahaan untuk menghindari atau mengurangi dampak ancaman eksternal. Strategi yang dapat diterapkan, yaitu:

a) Memperluas jaringan pemasaran

Strategi ini ditempuh karena adanya kekuatan kualitas jamur yang baik dan ancaman masuknya jamur tiram dari daerah lain. Untuk menempuh strategi tersebut, petani jamur tiram harus memasarkan jamur tiram ke tempat lain, tidak hanya menjual didaerah sekitar produksi atau hany ke pengecer saja. Informasi pasar yang lebih memadai mengenai potensi produk yang laku di pasaran sangat penting bagi petani jamur tiram. Informasi pasar yang lengkap juga akan memudahkan penentuan jaringan pemasaran yang sesuai untuk dikembangkan agar dapat menjangkau seluruh potensi pasar yang ada.

4. Strategi W-T (Weaknesses - Threaths)

Strategi W-T adalah strategi yang ditujukan untuk mengurangi kelemahan internal yang dimiliki dan menghindari ancaman eksternal yang ada. Strategi yang dapat diterapkan, yaitu:

a) Memperluas akses informasi pasar dengan penggunaan teknologi informasi

Strategi ini terkait dengan bauran pemasaran tentang distribusi produk. Daerah pemasaran jamur Tiram di Kota Mataram saat ini masih sangat terbatas yaitu di kawasan sekitar hasil produksi. Pencarian informasi pasar tentang daerah pemasaran lain yang tepat untuk memasarkan produk perlu dilakukan. Dengan penggunaan teknologi informasi seperti media cetak dan media elektronik dapat membantu petani jamur tiram dalam memperluas daerah pemasarannya. Informasi yang diperoleh dapat berupa informasi mengenai jangkauan pasar. Hal ini perlu dilakukan karena semakin luas daerah pemasaran yang dimiliki, maka akan semakin meningkat penjualan produk.

Tahap terakhir dalam perumusan strategi pemasaran adalah tahap keputusan dengan menggunakan Matriks QSPM (Quantitative Strategic Planning Matrix). Adapun hasil perhitungan Matriks QSPM yaitu perkalian antara rata-rata bobot faktor-faktor strategi internal dan eksternal dengan nilai daya tarik (AS) dapat dilihat pada Lampiran 3. Matriks QSPM.

Berdasarkan Lampiran 3 urutan pemilihan strategi berdasarkan total nilai kemenarikannya adalah sebagai berikut:

1. Meningkatkan nilai tambah dengan pengolahan produk jamur tiram segar $(5,906)$.

2. Memperluas jaringan pemasaran $(5,888)$

3. Meningkatkan promosi jamur tiram $(5,641)$.

4. Memperluas akses informasi pasar dengan penggunaan teknologi informasi $(5,467)$.

5. Melakukan pengemasan dengan berbagai ukuran $(5,172)$.

6. Menjaga dan meningkatkan kualitas produk $(4,545)$.

Nuraini, U., Sukardi, L., dan Efendy 


\section{KESIMPULAN DAN SARAN}

\section{Kesimpulan}

Berdasarkan hasil penelitian dan analisis dapat disimpulkan sebagai berikut:

1. Saluran pemasaran jamur tiram di Kota Mataram ada dua, yaitu: (1) Produsen Konsumen Akhir. (2) Produsen - Pedagang Pengecer - Konsumen Akhir.

2. Faktor internal pemasaran jamur tiram di Kota Mataram yang menjadi kekuatannya adalah: Kualitas jamur tiram yang baik, besarnya modal yang cukup, penetapan harga yang terjangkau oleh konsumen, kontinuitas produksi; dan faktor internal kelemahannya adalah: Produk jamur tiram cepat rusak, jangkauan pasar hanya terbatas pasar lokal, bentuk produk yang dijual gelondongan. Sedangkan untuk faktor eksternal pemasaran jamur tiram yang menjadi peluangnya adalah: Jamur tiram dapat diolah menjadi produk turunan, perkembangan pasar online dan pasar modern, dukungan kebijakan pemerintah; dan faktor eksternal ancamannya adalah: Masuknya produk sejenis dari daerah lain, berkembangnya produk substitusi.

3. Strategi pemasaran yang dapat dilakukan oleh petani jamur adalah pertumbuhan agresif (growth oriented strategy) yaitu dengan memperluas pangsa pasar,dan melalui peningkatkan nilai tambah melalui pengolahan produk jamur tiram segar.

\section{Saran}

1. Bagi pemerintah dan pihak terkait, diharapkan pemerintah sebaiknya lebih sering melakukan pembinaan terhadap perkembangan usaha jamur tiram khususnya yang ada di Kota Mataram agar usaha jamur tiram tersebut lebih banyak mendapat inovasi dan dukungan untuk mengembangkan usaha pemasaran jamur tiram.

2. Bagi petani jamur tiram, diharapkan petani jamur tiram dapat mempertahankan posisi usaha yang ada dengan meningkatkan produksi, melakukan pengolahan produk dari jamur tiram segar dan promosi secara efektif seperti promosi secara langsung kepada konsumen, menggunakan perkembangan teknologi dalam memperkenalkan produk, memperbaiki tampilan produk, memperbaiki tampilan produk untuk menarik konsumen.

3. Bagi peneliti selanjutnya, diharapkan dapat meneliti strategi pemasaran jamur tiram dengan lebih mendalam lagi dan informan yang lebih banyak lagi agar dapat menghasilkan penelitian yang lebih umum terkait upaya-upaya mencapai peningkatan usaha jamur tiram.

\section{DAFTAR PUSTAKA}

Agrina. (2009). Budidaya Jamur Tiram. Penebar Swadaya. Jakarta.

Candra, R., \& Situmorang, S. (2014). Analisis usahatani dan pemasaran jamur tiram dengan cara konvensional dan jaringan (multi level marketing) di provinsi lampung. Jurnal Ilmu Ilmu Agribisnis: Journal of Agribusiness Science, 2(1), 38-47.

David, F. R. (2006). Manajemen Strategis Konsep. Jakarta: PT Prenhalindo.

Hermawan, E., Soetoro, S., \& Hardiyanto, T. (2017). Strategi Pemasaran Jamur Tiram (Studi Kasus Pada Perusahaan Margi Mulyo di Desa Adimulya Kecamatan Wanareja Kabupaten Cilacap). Jurnal Ilmiah Mahasiswa Agroinfo Galuh, 3(3), 338-343.

Nuraini, U., Sukardi, L., dan Efendy 
Marini, I. A. K., Nopiari, I. A., \& Artika, I. B. E. (2019). Analisis Strategi Pemasaran Jamur Tiram Putih (Pleurotus Ostreatus) Pada Usaha Dagang Kenanga Di Kecamatan Ampenan Kota Mataram. Ganec Swara, 13(2), 375-383.

Meitasari, Y. (2011). Studi Tataniaga Jamur Tiram Putih (Pleurotus ostreatus) di Kota Samarinda. Jurnal Agribisnis, 8(2). http://agribisnisfpumjurnal. files. com/201 2/03/jurnal, 8.

Mundiyah, A. I., Septiadi, D., Nabila, S., Sari, N. M. W., \& Zeamita, N. M. (2020). Rebranding Produk Keripik Jamur Tiram Untuk Peningkatan Penjualan Pada Umkm Sporamushroom. Jurnal Pengabdian Pada Masyarakat Membangun Negeri, 4(1), 77-83.

Nazir, M. (2017). Metode Penelitian. Ghalia Indonesia. Bogor.

Pasaribu, T. Permana, DR. dan Alda, ER. 2002. Aneka Jamur Unggulan yang Menembus Pasar. PT Gramedia Widiasarana Indonesia. Jakarta.

Rangkuti, F. (2000). Analisis SWOT Teknik Membedah Kasus Bisnis. PT Gramedia Pustaka Utama. Jakarta

Sarina. (2012). Analisis Usahatani Jamur Tiram: Studi Kasus di Desa Watas Marga II Kecamatan Curup Selatan Kabupaten Rejang Lebong. Jurnal Agribisnis Vol. IV http://umb.ac.id/faperta/?p=131

Septiadi, D., \& Mundiyah, A. I. (2020). Strategi Pengembangan Usaha Tani Sayuran Berbasis Pertanian Organik. Agrifo: Jurnal Agribisnis Universitas Malikussaleh, $5(1), 35-43$.

Soenanto, H. (2000). Jamur Tiram Budidaya dan Peluang Usaha. Aneka Ilmu. Semarang.

Sukanteri, N. P., Suparyana, P. K., Suryana, I. M., Yuniti, D., \& Verawati, Y. (2020). Manajemen Pengendalian Mutu Dalam Produksi Agribisnis pada Kelompok Wanita Tani Ayu Tangkas. JURNAL GALUNG TROPIKA, 9(3), 209-222.

Suparyana, P. K., Sukanteri, N. P., \& Septiadi, D. (2020). Stategi Pengembangan Usaha Produksi Kue Pada Kelompok Wanita Tani Ayu Tangkas Di Kecamatan Selemadeg Timur, Bali. AGRISAINTIFIKA: Jurnal Ilmu-Ilmu Pertanian, 4(1), 4659. 